\title{
BIOLOGICAL STUDIES ON CITRUS BROWN MITE EUTETRANYCHUS ORIENTALIS (KLEIN) (TETRANYCHIDAE: ACARINA) WHEN FED ON LEAVES OF CARICA PAPAYA VARIETIES UNDER LABORATORY CONDITIONS
}

\author{
ABD-EL-WAHED, N.M., K.M. EL-SYAED and MONA S.EL-GHOBASHI
}

Plant Protection Research Institute, ARC, Dokki, Giza

(Manuscript received $2^{\text {nd }}$ January 2012)

\begin{abstract}
This work was carried out under laboratory conditions to study the biological aspects of citrus brown mite, Eutetranychus orientalis (Kelin) when fed on leaves of carica papaya (Solo and Fershold) varieties under laboratory conditions of 25 and $30^{\circ} \mathrm{C}$ and $(60 \pm 5 \%$ R.H.). The biological aspects of E.orientalis could be studied, the incubation period, life cycle, generation and life span for both female and male, in addition to female pre-ovipostion, oviposition, post-oviposition, and total number of female's deposited eggs. Life cycle lasted (13.7 \& 11.1) and (12.7 \& 10.5) days with solo variety at 25 and $30^{\circ} \mathrm{C}$ for female and male, respectively, while it elongate with fershold to (15.1\& 13.3) and (14.2 \& 12.2) days at the same pattern. On the other hand, female pre-oviposition, oviposition and post-oviposition periods durated (1.9 \& 1.2), (10.3 \& 8.7) and (3.2 \& 2.1) days respectively at 25 and $30^{\circ} \mathrm{C}$ on solo variety, while, on fershold variety it lasted (1.6 \& 1.00), (12.3 \& 10.6) and (2.7 \& $2.2)$ days, respectively. Solo carica papaya variety was more favorable host of E.orientalis development and fecundity than fershold variety. Therefore, solo variety more susceptible to citus brown mite E.orientalis.
\end{abstract}

\section{INTRODUCTION}

The citrus brown mite Eutetranychus orientalis (Klein) attacks citrus and is a persistent pest in upper Egypt. It prefers sour lemon rather than mandarine, orange or sweet lemon, and also infests castor, peach, cucurbits, beans and cotton. Mites are usually on the upper side of leaf surface along the midrib. Severe infestations occur during summer, especially in nurseries. About 19 generations occur per year depending on temperature tranging from 16 to $30^{\circ} \mathrm{C}$, one generation takes $1.5-11$ weeks, eggs hatch in 4-18 days, immatures develop in 4-53 days and adult longevity lasts 6-20 days. An average female lays 10-25 eggs Zahar (1984).

Citurs brown mite E.orientalis was record recently on carica papaya in different localilies of Egypt and cause sever damage for leaves and reduction of the quality and quantity of the production. (Bana and Channa 1972, Lai 1977, Salmon 1978, Lu and Wang 2005 and Zhou et al., 2006). 
This work aims to study the effect of two varieties of carica papaya and temperature on biological aspects of citrus brown mite E.orientalis under laboratory conditions.

\section{MATERIALS AND METHODS}

To study the effect of different degree of temperature and host plant variety on the biology of the citurs brown mite Eutetranychus orientalis (Klein), the following technique was applied: Leaves of carica papaya varieties solo and fershold were used for rearing the mite under the laboratory conditions of 25 and $30^{\circ} \mathrm{C}$ and $60 \pm 5 \%$ R.H. Leaves were taken and well washed with running water to remove any possible residuals or mites which may be found were made and surrounded by tangle foot, which acts as a barrier to prevent mite individuals from ascaping. Leaves were placed on cotton wool in petri dishes of $12.5 \mathrm{~cm}$ diameter suitable moisture was maintained by adding few drops of water.

Pure culture of E.orientalis was maintained at the laboratory. Newly hatching larvae were transferred singly to leaf discs (I cm diameter) and left to continue its life span. Newly emerged females were capulated and left to deposited eggs until dead. Examination was made twice daily, early morning and before sunset. Biological aspects of incubation, life cycle, generation life span of both female and male, in addition to female preovipesition, oviposition and postoviposition periods were recorded.

\section{RESULTS AND DISCUSSION}

The biological aspects of Eutetranychus orientalis (Klein) estimated the development stages and its fecundity on carica papaya varieties under laboratory conditions of temperature 25 and $30^{\circ} \mathrm{C}$ and $60 \pm 5 \%$ R.H.

\section{Duration of immature Stages}

\section{1- Incubation period}

Data in tables $(1 \& 2)$ demonstrated that the incubation period of female and male lasted $(4.8 \pm 0.62 \& 4.6 \pm 0.52)$ and $\left(3.9 \pm 0.59 \& 3.8 \pm \_0.38\right)$ days at 25 and $30^{\circ} \mathrm{C}$ respectively, when they fed on solo variety, while on fershold variety it reached to $(5.3 \pm 0.81 \& 4.9 \pm 0.58)$ and $(4.8 \pm 0.75 \& 4.6 \pm 0.45)$ days for female and male at the same trend.

\section{2- Immature Periods}

1- Female and male larval stage stayed $(3.6 \pm 0.66 \& 3.4 \pm 0.44)$ and $(2.8 \pm$ $0.38 \& 2.5 \pm 0.41)$ days when fed on solo variety, while it durated $(3.9 \pm$ 
$0.83 \& 3.8 \pm 0.26)$ and $(3.5 \pm 0.27 \& 3.1 \pm 0.56)$ days on fershold variety, at $25 \& 30^{\circ} \mathrm{C}$ and $60 \pm 5 \% \mathrm{RH}$.

2- The protonymphal stage lasted $(2.5 \pm 0.44 \& 2.3 \pm 0.37)$ and $(2.1 \pm 0.51 \&$ $2.00 \pm 0.50$ ) days for female and male at 25 and $30^{\circ} \mathrm{C}$, at the same pattern when fed on leaves of solo variety. While, this period lasted $(2.8 \pm 0.34 \& 2.6$ $\pm 0.52)$ and $(2.2 \pm 0.38 \& 2.1 \pm 0.56)$ days, for both females and male when mite fed on leaves of fershold variety respectively.

3- The deutonymphal stage durated $(2.7 \pm 0.54 \& 2.4 \pm 0.44)$ and $(2.3 \pm 0.39 \& 2.1 \pm 0.24)$ days for female and male on solo variety, respectively, while it elongate to $(3.1 \pm 0.48 \& 2.8 \pm 0.82)$ and $(2.7 \pm 0.38 \& 2.3 \pm 0.47)$ days respectively for female and male when they fed on leaves of fershold variety at $25 \& 30^{\circ} \mathrm{C}$ and $60 \pm 5 \% \mathrm{RH}$.

\section{1- Total Immature Periods}

The average total immature stages of females and males were $(8.8 \pm 0.97 \&$ $8.1 \pm 0.86)$ and $(7.2 \pm 0.72 \& 6.6 \pm 0.69)$ days on solo variety, while it averaged $(9.8 \pm 1.07 \& 9.3 \pm 52)$ and $(8.5 \pm 0.38 \& 7.6 \pm 1.18)$ days on fershold variety respectively.

\section{2- Life Cycle}

Data in Tables $(1,2)$ revealed that the average life cycle period lasted (13.7 $\pm 1.06 \& 12.7 \pm 1.28)$ and $(11.1 \pm 0.91 \& 10.5 \pm 0.87)$ days for female and male when mite fed on leaves of solo variety at 25 and $30^{\circ} \mathrm{C}$, respectively. Female and male life cycle was longer with fershold variety than solo variety as well as at $25^{\circ} \mathrm{C}$ than $30^{\circ} \mathrm{C}$, where by the life cycle of female and male at 25 and $30^{\circ} \mathrm{C}$ durated $(15.1 \pm 0.63$ $\& 14.2 \pm 0.38)$ and $(13.3 \pm 0.84 \& 12.2 \pm 1.29)$ days, when they reared on leaves of fershold variety.

Table 1. Duration (days) of Eutetranychus orientalis (Klein) on leaves of solo carica papaya variety at 25 and $300 \mathrm{C}$ and relative humidity $60+5 \%$.

\begin{tabular}{|c|c|c|c|c|}
\hline \multirow{3}{*}{$\begin{array}{c}\text { Developmental } \\
\text { Stages }\end{array}$} & \multicolumn{4}{|c|}{ Duration in days } \\
\hline & \multicolumn{2}{|c|}{ Mean $\pm S D$ at $25^{\circ} \mathrm{C}$} & \multicolumn{2}{|c|}{ Mean \pm SD at $30^{\circ} \mathrm{C}$} \\
\hline & Female & Male & Female & Male \\
\hline Incubation Period & $4.8 \pm 0.62$ & $4.6 \pm 0.52$ & $3.9 \pm 0.59$ & $3.8 \pm 0.38$ \\
\hline Larva & $3.6 \pm 0.66$ & $3.4 \pm 0.44$ & $2.8 \pm 0.38$ & $2.5 \pm 0.41$ \\
\hline Protonymph & $2.5 \pm 0.44$ & $2.3 \pm 0.37$ & $2.1 \pm 0.51$ & $2.00 \pm 0.50$ \\
\hline Deutonymph & $2.7 \pm 0.54$ & $2.4 \pm 0.44$ & $2.3+0.39$ & $2.1+0.24$ \\
\hline Total Immature & $8.8 \pm 0.97$ & $8.1 \pm 0.86$ & $7.2 \pm 0.72$ & $6.6 \pm 0.69$ \\
\hline Life Cycle & $13.7 \pm 1.06$ & $12.7 \pm 1.28$ & $11.1 \pm 0.91$ & $10.5 \pm 0.87$ \\
\hline Generation Period & $15.5 \pm 1.01$ & - & $12.42 \pm 0.95$ & - \\
\hline Longevity & $15.5 \pm 1.39$ & $9.75 \pm 1.03$ & $12.00 \pm 1.13$ & $7.19 \pm 1.34$ \\
\hline Life Span & $29.5+1.95$ & $22.43+1.67$ & $23.17 \pm 1.27$ & $17.64+1.65$ \\
\hline
\end{tabular}


1428 BIOLOGICAL STUDIES ON CITRUS BROWN MITE EUTETRANYCHUS ORIENTALIS (KLEIN) (TETRANYCHIDAE: ACARINA) WHEN FED ON LEAVES OF CARICA PAPAYA VARIETIES UNDER LABORATORY CONDITIONS

Table 2. Duration (days) of Eutetranychus orientalis (Klein) on leaves of fershold carica papaya variety at 25 and $30 \circ \mathrm{C}$ and relative humidity $60+5 \%$.

\begin{tabular}{|c|c|c|c|c|}
\hline \multirow{3}{*}{$\begin{array}{c}\text { Developmental } \\
\text { Stages }\end{array}$} & \multicolumn{4}{|c|}{ Duration in days } \\
\hline & \multicolumn{2}{|c|}{ Mean \pm SD at $25^{\circ} \mathrm{C}$} & \multicolumn{2}{|c|}{ Mean \pm SD at $30^{\circ} \mathrm{C}$} \\
\hline & Female & Male & Female & Male \\
\hline Incubation Period & $5.3 \pm 0.81$ & $4.9 \pm 0.58$ & $4.8+0.75$ & $4.6 \pm 0.45$ \\
\hline Larva & $3.9 \pm 0.83$ & $3.8 \pm 0.26$ & $3.5 \pm 0.27$ & $3.1 \pm 0.56$ \\
\hline Protonymph & $2.8 \pm 0.34$ & $2.6 \pm 0.52$ & $2.2 \pm 0.38$ & $2.1 \pm 0.56$ \\
\hline Deutonymph & $3.1 \pm 0.48$ & $2.8 \pm 0.82$ & $2.7 \pm 0.38$ & $2.3 \pm 0.47$ \\
\hline Total Immature & $9.8 \pm 1.07$ & $9.3 \pm 0.52$ & $8.5 \pm 0.38$ & $7.06 \pm 1.18$ \\
\hline Life Cycle & $15.1 \pm 0.63$ & $14.2 \pm 0.38$ & $13.3 \pm 0.84$ & $12.2 \pm 1.29$ \\
\hline Generation Period & $16.75 \pm 0.92$ & - & $14.31 \pm 0.70$ & - \\
\hline Longevity & $16.6+2.26$ & $11.16 \pm 1.17$ & $13.8+1.54$ & $9.14 \pm 1.34$ \\
\hline Life Span & $31.79+2.67$ & $25.75+1.21$ & $27.2+1.18$ & $21.36+1.03$ \\
\hline
\end{tabular}

Table 3. Longevity and Fecundity of Eutetranychus orientalis (Klein) when fed on leaves of solo carica papaya variety

\begin{tabular}{|c|c|c|c|c|c|}
\hline \multirow[t]{2}{*}{ Temperature } & \multirow{2}{*}{$\begin{array}{c}\text { Pre- } \\
\text { Oviposition } \\
\text { Period } \\
\end{array}$} & \multirow{2}{*}{$\begin{array}{c}\text { Oviposition } \\
\text { Period }\end{array}$} & \multirow{2}{*}{$\begin{array}{c}\text { Post- } \\
\text { Oviposition } \\
\text { Period }\end{array}$} & \multicolumn{2}{|c|}{ Fecundity } \\
\hline & & & & $\begin{array}{l}\text { No.f } \\
\text { eggs }\end{array}$ & $\begin{array}{l}\text { Daily } \\
\text { rate }\end{array}$ \\
\hline $25^{\circ} \mathrm{C}$ & $1.9 \pm 0.58$ & $10.3 \pm 1.70$ & $3.2 \pm 0.63$ & $19+2.62$ & $2.37 \pm 0.14$ \\
\hline $30^{\circ} \mathrm{C}$ & $1.2+0.34$ & $8.7 \pm 0.89$ & $2.1 \pm 0.56$ & $31+2.31$ & $3.87 \pm 0.23$ \\
\hline
\end{tabular}

Table 4. Longevity and Fecundity of Eutetranychus orientalis (Klein) when fed of leaves of fershold carica papaya variety

\begin{tabular}{|c|c|c|c|c|c|}
\hline Temperature & Pre- & Oviposition & \multicolumn{2}{|c|}{ Post- } \\
& $\begin{array}{c}\text { Oviposition } \\
\text { Period }\end{array}$ & Period & Oviposition & Fo.f & Daily \\
& & & Period & eggs & rate \\
\hline $25^{\circ} \mathrm{C}$ & $1.6 \pm 0.47$ & $12.3 \pm 1.82$ & $2.7 \pm 0.62$ & $16 \pm 2.31$ & $2 \pm 4.11$ \\
\hline $30^{\circ} \mathrm{C}$ & $1.00 \pm 0.42$ & $10.6 \pm 1.85$ & $2.2 \pm 0.75$ & $22 \pm 3.1$ & $2.75 \pm 0.16$ \\
\hline
\end{tabular}

\section{5- Female Longevity}

Data in tables ( $3 \& 4)$ demonstrated that, the average of pre-oviposition period lasted $1.9 \pm 0.58$ and $1.2 \pm 0.34$ days on solo variety at 25 and $30^{\circ} \mathrm{C}$, respectively, while reached to $1.6 \pm 0.47$ and $1.00 \pm 0.42$ days on fershold variety at the previous temperature. The oviposition period of female durated $(10.3 \pm 1.70 \&$ $8.7 \pm 0.89)$ and $(12.3 \pm 1.82 \& 10.6 \pm 1.85)$ days on solo and fershold varieties at 25 and $30^{\circ} \mathrm{C}$, respectively, the average post-oviposition period were $(3.2 \pm 0.63 \&$ 
$2.1 \pm 0.56)$ and $(2.7 \pm 0.62 \& 2.2 \pm 0.75)$ days on the above mentioned carica papaya varieties at the previous temperature.

The average generation period lasted $(15.5 \pm 1.01 \& 12.42 \pm 0.95)$ and $(16.75 \pm 0.92 \& 14.13 \pm 0.70)$ days at 25 and $30^{\circ} \mathrm{C}$ on solo and fershold varieties, respectively.

Female longevity lasted (15.5 $\pm 1.39 \& 12.00 \pm 1.13)$ and $(16.6 \pm 2.26 \& 13.8 \pm 1.54)$ while male adulthood durated $(9.75 \pm 1.03 \& 7.14 \pm$ $1.34)$ and $(11.16 \pm 1.17 \& 9.14 \pm 1.34)$ days when they fed on the also mentioned hosts at 25 and $30^{\circ} \mathrm{C}$.

Females deposited an average of 19 and 31 eggs with a daily rate of 2.37 and 3.87 eggs at 25 and $30^{\circ} \mathrm{C}$, when females fed on leaves of solo variety, while the average number of deposited eggs decreased to 16 and 22 eggs with a daily rate of 2.0 and 2.75 eggs on leaves of fershold variety at the previous temperature. Solo leaves carica papaya variety, highly stimulated of E.orientalis fecundity than fershold variety.

\section{6- Life Span}

The average life span of E.orientalis when, reared on leaves of solo variety were $(29.05 \pm 1.95 \& 22.43 \pm 1.67)$ and $(23.17 \pm 1.27 \&$ $17.64 \pm 1.65)$ days of female and male at 25 and $30^{\circ} \mathrm{C}$, respectively, while it averaged $(31.79 \pm 2.67 \& 25.75 \pm 1.21)$ and $(27.2 \pm 1.18 \& 21.36 \pm 1.03)$ days of female and male at the previous temperature when this mite reared on leaves of fershold variety. Female life span longer than male under different conditions.

The effect of two carica papaya varieties solo and fershold on the biology of E.orientalis was investigated at constant temperature of 25 and $30^{\circ} \mathrm{C}$ and relative humidity $60 \pm 5 \%$, these results demonstrated that leaves of solo variety more favorable for E.orientalis development and fecundity than leaves of fershold variety, thus solo variety was more susceptible to oriental red mite E.orientails infestation than fershold variety. On the other hand the biodata showed that positive relationship between female fecundity and temperature. This results agreements with, Banu and Channa (1972) Jeppson et al (1975), Lai (1977), Rasmy (1978), Salmon (1978), Dhooria (1981), Smith-Mayer (1981), Dhooria and Butani (1984), Hafez et al (1984), Zahar (1984), Tanigoshi et al (1990) Yadav et al (2003), Lu and Wang (2005) and Zhou et al(2006). 
1430 BIOLOGICAL STUDIES ON CITRUS BROWN MITE EUTETRANYCHUS ORIENTALIS (KLEIN) (TETRANYCHIDAE: ACARINA) WHEN FED ON LEAVES OF CARICA PAPAYA VARIETIES UNDER LABORATORY CONDITIONS

\section{REFERENCES}

1. Banu, K. and B. Channa. 1972. Plant feeding mites of India 1. A preliminary account of the biology of the spider mite Eutetranychus orientalis (Klein) (Acarina: Tetranychidae. Mysore Journal of Agricultural Sciences. 6 (3): 253-268.

2. Dhooria, M.S. 1981. Studies on oviposition preference, host-rang and seasonal incidence of Eutetranychus orientalis (Klein) (Acari: Tetranychidae) in Delhi. Indian Journal of Acarology. 1981 Publ, 6 (1/2) : 77-83.

3. Dhooria, M.S. and D.K. Butani. 1984. Citrus mite Eutetranychus orientalis (Klein) and its control. Pesticides, 18 (10): 35-38.

4. Hafez, S.M., M.S., El-Zemaity, N.M. Ebaid and S.K. Kalif. 1984. Effect of female crowding on certain biological aspects of the citrus brown mite, Eutetranychus orientalis (Kelin). Annals of Agricultural Science Ain Shams University, 29 (2): 1109-1117.

5. Jeppson, L.R., H.H. Keifer and E.W. Baker. 1975. Mites injurous to economic plants, University of California Press, Berkeley, U.S.A., PP. 153-155.

6. Lai, L. 1977. Studies on the biology of the mite Eutetranychus orientalis (Kelin) (Tetranychidea: Acarina). Entomon., 2 (1): 53-57.

7. Lu, C.T. and C.L. Wang. 2005. An investigation of spider mites on papaya and reevaluation of some acaricides. Plant protection Bulletin Taipei 47 (3): 273-279.

8. Rasmy, A.H. 1978. Biology of the citrus brown mite, Eutetranychus orientalis as affected by some citrus species. Acarologia 19 (2): 222-224.

9. Salmon, A.G.A. 1978. Effect of host plant species and temperature in population increase of the citrus brown mite Eutetranycus orientalis (Klein). Bulltin de La Societe Entomoligque d' Egypt. 1978/1979 Publ (62): 147-154.

10. Smith-Mayer, M.K.P. 1981. Mite pests of crops in southern Africa. Science Bulletin, Department of Agriculture and Fisheries, Republic of South Africa No. 397, PP. 6567.

11. Tanigoshi, L.K., M., Bahd oushed, J.M. Babcock and R. Sawaqed. 1990. Euseius scutalis (A.H.) a predator of Eutetranychus orientalis (Klein) (Acari: Phytoseiidae , 
Tetranychidae) in Jordon: Toxicity of some acaricides of E.orientalis. Arab Journal of $A$ ant Protection $8,114-120$.

12. Yadav, S.K., Ashok, S. and L.N. Yadav. 2003. Biology of mite, Eutetranychus orientalis (Klein) at armbient temperature. Annals of Agric Bio Research. 8 (1): 73-76.

13. Zaher, M.A. 1984. Survey and Ecological studies on phyto phagous, predaceous and soil mites in Egypt. Phytophagous mites. 228 Fac. F Agric. Cairo Univ.

14. Zhou, C.G, W., Zhang, L., Oiao, X. Sun and Z. Wang. 2006. The biological characteristics effective accumulate temperature and occurrence regulation of Eutetranychus orientalis. Scientia Silvae Sinicae, 42 (5): 89-93. 


\section{دراسات بيولوجية لاكاروس الموالح البنى Eutetranychus orientalis}

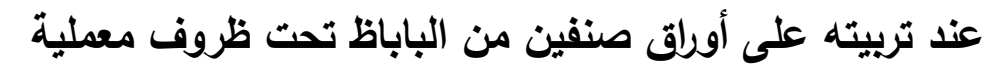

$$
\begin{aligned}
& \text { نزيه محمد عبد الواحد كرم محمد السيد ، منى إمام سيلمان الغباثى } \\
& \text { معهُ بحوث وقاية النباتات - مركز البحوث الزراعية - الدقى - الجيزة }
\end{aligned}
$$

يعتبر الباباظ من الفاكهة الاستوائية وقد نجحت زراعته فى مصر بمعظم المحافظات وقد وجد

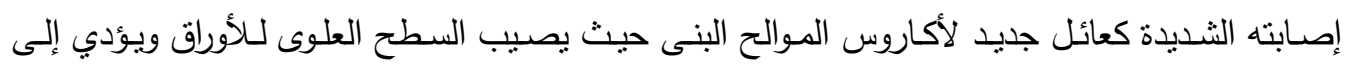

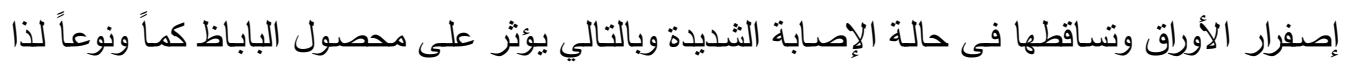

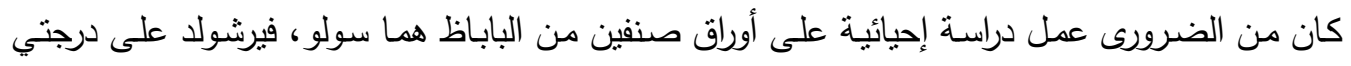

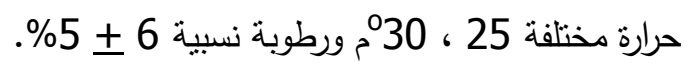

وتهدف الدراسـة إلى معرفـة تأثنير صنفين من البابـاظ ودرجـة الحرارة على تطور وخصـوبة

$$
\text { أكاروس الموالح البنى ومدى قابلية الصنفين للإصابة بهذه الآفة. }
$$

وتتشير النتائج المتحصل عليها بأن دورة حياة أكاروس الموالح البنى عند نربيته على أوراق

الباباظ صنف سولو بلغت 13.7 ، 11.1 يوماً فى حالة الأنثى أما فى حالة الذكر فقد بلغت الت 12.7 ، 12.7 ،

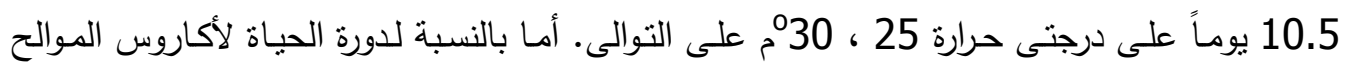
البنى عند تربيته على أوراق الباباظ صنف فيرشولد فقد بلغت 15.1 ، 13.3 ، 13.3 يوماً فى حالة الأنثى أما

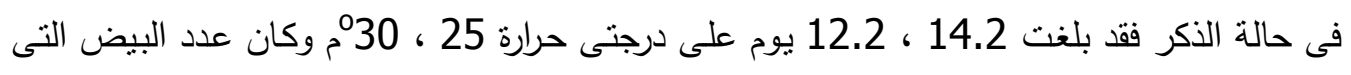

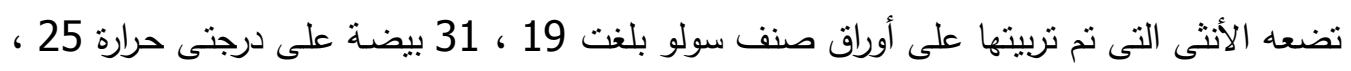

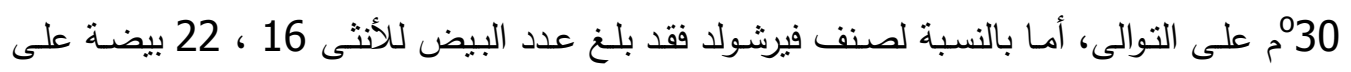
درجتى حرارة 25 ، 300م على التوالى.

على ضوء هذه النتائج نجد أن صنف سولو أكثر قابلية للإصـابة بأكاروس الموالح البنى

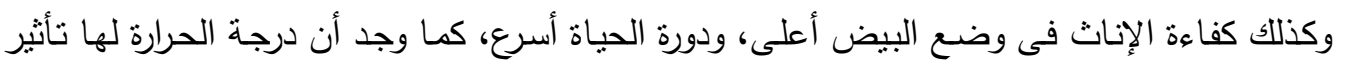
إيجابي على نشاط وخصوبة الإناث فى وضع البيض. ليض. 